Title: Durand of St.-Pourçain on Reflex Acts and State Consciousness

Author: Peter John Hartman

Affiliation: Associate Professor, Loyola University Chicago

Contact: phartman@luc.edu

Keywords: Durand of St.-Pourçain, State Consciousness, Introspective Consciousness, Reflex Acts

Abstract: Some of my mental states are conscious and some of them are not. Sometimes I am so focused on the wine in front of me that I am unaware that I am thinking about it; but sometimes, of course, I take a reflexive step back and become aware of my thinking about the wine in front of me. What marks the difference between a conscious mental state and an unconscious one? In this paper, I focus on Durand of St.-Pourçain's rejection of the higher-order theory of state consciousness, according to which a mental act is conscious when there is another, suitably related, mental (reflex) act that exists at the same time with it. Durand rejects such higher-order theories on the grounds that they violate the thesis that a given mental power can have or elicit only one mental act at a given time. I first go over some of Durand's general arguments for this thesis. I then turn to Durand's application of the thesis to the issue of state consciousnes and reflex acts. I close by considering the objection that Durand's same-order theory of state consciousness makes consciousness ubiquitous. 


\section{Durand of St.-Pourçain on Reflex Acts and State Consciousness.}

Some of my mental states are conscious and some of them are not, or, put in other terms, I am aware of some of my mental states and unaware of others. Sometimes I am so focused on the wine in front of me that I am unaware that I am thinking about it; but sometimes, of course, I take a reflexive step back and become aware of my thinking about the wine in front of me. What marks the difference between a conscious mental state and an unconscious one? For some philosophers, both medieval and contemporary, a mental state is conscious when there is another, suitably related, mental state that exists at the same time as it. On this account, state consciousness is a matter of a higher-order (or reflex) mental state (or act) being present in the mind at the same time as a lower-order (or direct) state (or act). Call such a theory the higher-order theory. Other philosophers, both medieval and contemporary, reject the higher-order theory, endorsing instead a same-order theory. ${ }^{1}$

${ }^{1}$ In what follows, I will mostly focus on what is nowadays called introspective state consciousness (as with the example given: the explicit awareness of a mental state) as opposed to phenomenal state consciousness (the what it's like or qualitative feel one has when one is in a certain mental state, e.g., what it's like to taste wine). I will return to this distinction in the third section. For examples of contemporary higher-order theories, see, e.g., David Rosenthal, "Varieties of Higher-Order Theory," in Higher-Order Theories of Consciousness, ed. Gennaro (Amsterdam: John Benjamins, 2004), PAGEREF; for same-order theories, see, e.g., Uriah Kriegel, "The Same-Order Monitoring Theory of Consciousness," in Self-Representational Approaches to Consciousness, ed. Kriegel and Williford (MIT: MIT Press, 2006), 143-170. For medieval variants, see the taxonomy of views provided below in Section 2. Much of the discussion in the secondary literature on medieval views focuses on self-consciousness (or subject consciousness) that is, awareness of one's own self or soul - and not state consciousness awareness of one's own mental states or acts. For a book-length treatment of the former, see François-Xavier Putallaz, La connaissance de soi au XIIIe siècle (Paris: Vrin, 1991). For the latter, see, however, Christian Rode, Zugänge zum Selbst: innere Erfahrung in Spätmittelalter und Früher Neuzeit (Münster: Aschendorff, 2015) and Susan Brower-Toland, "SelfKnowledge, Self-Consciousness, and Reflexivity in Late Medieval Philosophy," in Companion to Cognitive Theory in the Later Middle Ages, ed. Friedman and Pickavé, Forthcoming. 
In this paper, I will focus on Durand of St.-Pourçain's (d. 1334) rejection of the higher-order theory and his defense of a same-order theory. Durand's basic argument against the higher-order theory is rather straightforward. He defends a general (and popular) thesis about the mind according to which a given mental power can have or elicit only one mental act at a given time: the intellect can elicit only one act of thinking at a time; sight only one act of seeing; and so on. Call this the one-act-at-a-time thesis. ${ }^{2}$ While many medieval philosophers put forward this thesis, ${ }^{3}$ Durand provides us with one of the most sustained defenses of it - and recognized as such by both his contemporaries and later commentators alike ${ }^{4}$ - in the third quaestio of his

${ }^{2}$ As we will see, this thesis entails that a single mental act might sometimes be about or represent multiple distinct things at the same time, e.g., I might think with one mental act about both smoke and fire at the same time. Such a thesis is opposed to the multiple-acts-at-a-time thesis according to which it is at least possible that a given mental power might elicit or have multiple mental acts at the same time, e.g., I might be thinking about smoke with one act while at the same time thinking about fire with a distinct act.

${ }^{3}$ See the authors and texts referenced in Russell Friedman, "On the Trail of a Philosophical Debate: Durand of St. Pourçain vs. Thomas Wylton on Simultaneous Acts in the Intellect," in Philosophical Debates in the Early Fourteenth Century, ed. Brown, Dewender, and Kobusch (Leiden: Brill, 2009), 433-64; "Mental Propositions before Mental Language," in Le langage mental du Moyen Âge à l'âge classique, ed. Biard (Leuven: Peeters, 2009), 95-115; Olivier Dubouclez, "Plura simul intelligere. Éléments pour une histoire du débat médiéval et renaissant sur la simultanéité des actes de l'intellect," Recherches de théologie et philosophie médiévales 81.2 (2014): 331-67; Dominik Perler, "Are Reflexive Acts Possible? A Late Medieval Controversy," in Miroir de l'amitié: Mélanges offerts à Joël Biard, ed. Grellard (Paris: Vrin, 2017), 213-26; and Robert Pasnau, After Certainty: A History of Our Epistemic Ideals and Illusions (Oxford: OUP, 2017), 96-98, 290-92.

${ }^{4}$ See, e.g., Thomas Wylton, Quaestio "Quod in intellectu possunt esse plures intellectiones simul" [= Quaestio "Quod in intellectu..."] (ed. Prospero Stella, "Le Quaestiones de libero arbitrio di Durando da S. Porciano," Salesianum 24 [1962]), 506-17; Guy Terrena, Quodl. (ed. Friedman, "On the Trail") 1.14, 458-61; Prosper de Reggio Emilia, Sent. (Vatican, lat. 1086) 1.1.3.1, ff. 79ra-81va; John Baconthorpe, Sent. (Cremona 1618) 2.10.1; Durandellus (aka Durandus de Aureliaco), Evidentia contra Durandum (ed. Stella 2003) 1.1; Peter Auriol, Sent. (Rome 1605) 2.11.3, a. 3; Francis of Marchia, Sent. (ed. Mariani 1997) 1.1.7; and Gregory of Rimini, Lectura (ed. Trapp, Marcolina, and Eckermann 1981) 1.1.1, a. 3. Late scholastics also regularly cited Durand's arguments, e.g., Thomas Cajetan, Gabriel Vasquez, Philippe Fabri, inter alia; see Dubouclez, "Plura simul intelligere," 332, fn. 2 , and the references therein. 
Quaestiones de libero arbitrio (henceforth: $Q L A),{ }^{5}$ where he also applies the thesis to the case of reflex and direct acts. Granted that, in general, a given mental power can have or elicit only one mental act at a time, it follows that state consciousness cannot be a matter of my mind's possession of a higherorder (reflex) act at the same time as my lower-order (direct) act of thinking about the wine in front of me. On Durand's view, the reflex and the direct act are not distinct simultaneous acts but one and the same act.

I will first go over two arguments that Durand puts forward in his general defense of the one-act-at-a-time thesis in $Q L A$ q. $3 .^{6} \mathrm{I}$ will then look in some detail at his application of this thesis to the problem of state consciousness. ${ }^{7}$

${ }^{5}$ For discussion of this text, see Josef Koch, Durandus de S. Porciano
(Münster: Aschendorff, 1927), chs. 6-7; Stella, "Le Quaestiones," 450-524;
Thomas Jeschke, Deus ut tentus vel visus: Die Debatte um die Seligkeit im
reflexiven Akt (ca. 1293-1320) (Leiden: Brill, 2010), ch. 6; and Stephen Dumont, "New Questions by Thomas Wylton," Documenti e studi sulla tradizione filosofica medievale 9 (1998): 367-73. The first two questions are revised from Durand's de aula and in vesperis debates, which themselves can be reliably dated to 1312 . However, it is not clear when Durand revised them and added the third quaestio, although it must have been shortly afterwards, for both Thomas Wylton (Quaestio "Quod in intellectu...") in 1312 and Guy Terrena (Quodl. 1.14) in 1313 respond to the third question. All references to the Quaestiones de aula, in vesperis, and de libero arbitrio are from the edition in Stella, "Le Quaestiones." QLA q. 3 along with Wylton's Quaestio "Quod in intellectu..." are reproduced, often verbatim, in Prosper de Reggio Emilia, Sent. 1.1.3.1 and John Baconthorpe, Sent. 2.10.1.

${ }^{6}$ While Durand appeals to the one-act-at-time thesis elsewhere (e.g., Sent. C, Prologus, q. 1, nn. 24, 28-29; 2.11.2, n. 10; 2.24.1, n. 5; 2.24.2, n. 25; Quaestio de aula, 455; Quaestio in vesperis, 453; and QLA q. 1, 474) in each of these locations he merely states the thesis but does not argue for it. In fact, in Sent. C, Prologus, q. 1, n. 24, Durand tells us that he has "already proven this elsewhere." Since there is nowhere else earlier in Sent. C where he could have done so, he must have had in mind some other work, likely QLA q. 3 (see Friedman, "On the Trail," 439). There are, however, two other places where Durand does defend the one-act-at-a-time thesis, namely, Sent. 1.38.2 and 2.38.3, where he puts forward versions of the cognitive means and unity-of-act arguments discussed below.

${ }^{7}$ Durand also discusses reflex acts in his defense of his (somewhat) famous claim that beatific enjoyment consists in a reflex act (e.g. Sent. B 1.1.1; Sent. C 1.1.2); for discussion, see Friedman, "On the Trail," 443-47 and Jeschke, Deus ut tentus vel visus. However, Durand does not discuss the question that concerns us here in that context, namely, whether or not the reflex act is really distinct from the direct act; instead, he adopts a more neutral stance: beatific enjoyment consits in a reflex act regardless of 
In the final section, I consider an objection to Durand's alternative proposal: If direct acts and reflex acts are not really distinct, then, it would seem, all my mental acts would be conscious.

\section{The One-Act-At-A-Time Thesis.}

In $Q L A$ q. 3 Durand identifies three cases where it might seem that a mental power can elicit or have multiple mental acts at the same time. Can the intellect elicit two thoughts at the same time each of which is precisely about the same object, e.g., two simultaneous thoughts about the roundness of the earth? (Case A: 488.17-489.14) Can the intellect elicit two thoughts at the same time about distinct but unrelated objects, e.g., one thought about sweetness alone and another (simultaneous) thought about whiteness alone? (Case C: 491.31-495.7) Finally, can the intellect elicit multiple thoughts at the same time about distinct objects as related to each other? That is, when the intellect judges that, say, whiteness is different from sweetness, does this require multiple thoughts at the same time, or will one thought suffice? (Case B: 489.15-491.30)

Since our concern is with reflex acts, we can safely pass over Cases A and C. Case A concerns thoughts about precisely one and the same object and Case $\mathrm{C}$ concerns thoughts about distinct objects as unrelated to each other; but during an episode of mental reflection I am thinking about two distinct objects as related to each other. For instance, when I think that I am thinking about the wine in front of me, I am thinking about the wine and also my direct thought about it; but these two objects (wine and my thought about the wine) are clearly related to each other: the latter is somehow of or about the former. It is Case B, then, that is relevant to the issue of state consciousness. Fortunately, the arguments Durand makes establishing the one-act-at-a-time thesis in Case B are quite independent from his arguments in the other two cases. ${ }^{8}$

whether or not this reflex act is distinct from the direct act (of seeing God). All references to Sent. C are from Venice 1571 (reprinted by The Gregg Press 1964). All references to Sent. A and Sent. B are from the ongoing critical edition from the Thomas Institute at the University of Cologne, unless otherwise noted. When the text of the various redactions is the same, I will signal this using, e.g., Sent. A/B (i.e., Sent. A and Sent. B). If all versions are the same, I will simply use Sent.

${ }^{8}$ For a discussion of Durand's arguments for the thesis in Cases A and C, see Friedman, "On the Trail," 434-35. This is also fortunate because these arguments (drawn largely from Aquinas) rest upon controversial ontological assumptions about mental acts; more precisely, they assume that a mental act is or at least requires an absolute thing added to the intellect (either the act itself or an intelligible species), an assumption that Durand tells us "at 
Let's look, then, at Case B. Durand adduces three arguments for the thesis that the intellect can have or elicit only one thought at a time when one is thinking about distinct things as related to each other. However, I will only look in detail at the first and second arguments as these bear most directly on Durand's analysis of reflex acts. The first is based on the technical notion of a 'cognitive means' (ratio cognoscendi). Durand writes:

When one thing is a cognitive means with respect to another thing (unum est ratio cognoscendi alterum), then both fall under the same [mental] act [at the same time]. For instance, we see color and quantity at the same time [with one mental act], for the former is a cognitive means with respect to the latter. However, when one thing is cognized through another thing through a relationship they have to each other (unum cognoscitur per aliud per habitudinem quam habent ad invicem), then the former is a cognitive means with respect to the latter. For instance, a cause is a cognitive means with respect to its effect $a$ priori, and an effect is a cognitive means with respect to its cause $a$ posteriori; and so on likewise with all other [relationships] (et consimiliter in omnibus aliis). (QLA q. 3, 489.30$35)^{9}$

present" (QLA q. 3, 488.28-29) he will maintain even though he had explicitly rejected such a view a few years earlier, e.g., in Sent. A 2.3.5. On the ontology of mental acts in Durand, see Peter John Hartman, "The Relation-Theory of Mental Acts: Durand of St.-Pourçain on the Ontological Status of Mental Acts," Oxford Studies in Medieval Philosophy 7 (2019): 186-211 and the references therein. Wylton, in fact, presses Durand on this point, arguing that if mental acts were relations, then many of Durand's arguments for the one-act-at-a-time thesis would fail dramatically (Quaestio "Quod in intellectu..." 508.37-509.7; 510.14-16; 514.13-28). Roughly, the idea is that whereas a single mental power cannot have multiple absolute forms inhering in it at the same time, it could all the same stand in multiple relations at the same time, a possibility Durand even admits. See also Prosper, Sent. 1.1.3.1, ff. 80va-b, 80rb, who embraces the view that mental acts are mere relations that a mental power stands in and so rejects the one-act-at-a-time thesis for precisely that reason. This might also explain why the only arguments for the one-act-at-a-time thesis we find in Durand's (early) Sent. A (1.38.2 and 2.38.3) are directed at Case B; as we will see such arguments do not make any such ontological assumptions (see the discussion below).

${ }^{9}$ All translations are my own, unless otherwise indicated. The same argument is later used by Palude, e.g., Quodl. (Toulouse, Bibliothèque municipale 744) q. 11, f. 114rb; q. 6, ff. 101va, 102ra-b, and 104va. Durand adduces a similar argument in Sent. 2.38.3, applied to the case of the will (drawing from Aquinas, Summa theologiae 1.19.5), where he argues that an end is a cognitive means by which I grasp the means to that end and so both 
Call this the cognitive means argument. A cognitive means, as a first approximation, is something we use in order to think about something else. ${ }^{10}$ For instance, a statue of Hercules can be used as a cognitive means with respect to Hercules: I think about Hercules thanks to thinking about the statue in virtue of the (relationship of) resemblance that it bears with Hercules. (Of course, I can also think about the statue on its own without using it as a cognitive means; I might also think about Hercules on his own, if he is present, without the statue as a cognitive means; and I might even use Hercules as a cognitive means to think about the statue instead.) Now, in general, Durand tells us, whenever I think about $\mathrm{X}$ as related to $\mathrm{Y}$ (no matter how $\mathrm{X}$ is related to $\mathrm{Y}$ ), I must use one of them as a cognitive means with respect to the other, that is, I must use one of them to think about the other. However, again according to Durand, whenever $\mathrm{X}$ is a cognitive means with respect to Y, I must cognize both of them at the same time and with the same act. (I must cognize both Hercules and the statue at the same time and with the same act when I use the statue as a cognitive means to think about Hercules.) Hence, whenever I think about two things as related to each other, I must do so with one act and not multiple acts at the same time. For instance, when I make an a posteriori judgment that smoke is caused by fire, I am using smoke as the cognitive means with respect to fire, and so I must cognize both smoke and fire at the same time and with one and the same act.

One must admit that the cognitive means argument is somewhat underdeveloped. Even if we admit that such a judgment requires me to use smoke as a cognitive means with respect to fire, and so cognize both smoke and fire at the same time as a result, an opponent might still insist that such a judgment need not consist in a single mental act: multiple simultaneous mental acts - one about smoke, the other about fire - might well explain

are grasped with one act. See also $Q L A$ q. 3, 498.8-19. A similar argument can be found in Aquinas, e.g., Quodl. 7.1.2 and Summa contra gentiles 1.55; for discussion (and further texts), see Therese Scarpelli Cory, Aquinas on Human Self-Knowledge (Cambridge: CUP, 2014), 138-40.

${ }^{10}$ A cognitive means might be an uncognized cognitive means or a cognized one; an example of the former would be an intelligible or sensible species while an example of the latter would be an picture or image. An uncognized cognitive means (e.g., a species) is that through which I cognize something but not that which I cognize, that is, it is used to think about something else even though it is not itself thought about, e.g, I might think about Hercules through a species of Hercules without thinking about the species of Hercules. Durand here has in mind cognized cognitive means. In fact, he rejects uncognized cognitive means elsewhere. On this distinction, and Durand's rejection of species, see Peter John Hartman, "Durand of St.Pourçain and Thomas Aquinas on Representation," History of Philosophy Quarterly 30.1 (2013): 19-34. 
what needs to be explained. Durand has, in other words, failed to establish that the alternative - the multiple-acts-at-a-time thesis - is implausible.

Durand's second argument - which I will call the unity-of-act argument aims to do just that (ibid., 489.36-490.23). ${ }^{11}$ Consider a case of judging that whiteness is different from sweetness. According to Durand, appealing to Aristotle's De anima (3.2 426b17-23), in such a case there must not only be a unity of subject (i.e., one subject) but also a unity of power (i.e., one power). Further, according to Durand, the sorts of considerations that Aristotle puts forward establishing that such a case requires a unity of subject and power also establish that there must be a unity of act (i.e., one act). ${ }^{12}$

Let us step through Durand's argument here. Now, quite reasonably, Aristotle maintains that there must be one subject in order to judge that whiteness is different from sweetness. If Bob sees something white and I taste something sweet, then neither Bob nor I could judge that whiteness is different from sweetness. Hence, a unity of subject is required (ibid., 489.45-490.1). However, according again to Aristotle, one subject with only two distinct powers (sight and taste, say) will also be insufficient, for I cannot grasp sweetness by means of sight nor can I grasp whiteness by means of taste. Hence, we must posit a third mental power that grasps both whiteness and sweetness in order to judge that whiteness is different from sweetness, or, in other words, a unity of power is required in addition to a unity of subject (ibid., 490.1-4).

${ }^{11}$ For discussion of this argument, see Friedman, "Mental Propositions," 101-103. Palude (drawing from Durand) puts forward the same argument in Quodl. 6, f. 118va. A similar argument was put forward later by Hugh of Lawton (1320s); see Hester Gelber, "I Cannot Tell a Lie: Hugh of Lawton's Critique of William of Ockham on Mental Language," Franciscan Studies 44 (1984): 141-79. John of Jandun as well had considered (and rejected) a similar argument (Super libros Aristotelis de anima subtilissimae quaestiones [Venice 1552] 3.32); for discussion, see Dubouclez, "Plura simul intelligere," 339-42.

${ }^{12}$ Indeed, Durand thinks that Aristotle was committed to this further claim (ibid., 490.10-13): "It seems that the Philosopher was motivated to maintain a unity of power [...] because otherwise he would not have been able to maintain that there was a unity of act[...]" On Aristotle, see Victor Caston, "Aristotle on Consciousness," Mind 111.444 (2002): 751-815, who interprets Aristotle along the same lines and as thus subscribing to a sameorder theory. On medieval interpretations of Aristotle here, see Jack Zupko, "Self-Knowledge and Self-Representation in Later Medieval Psychology," in Mind, Cognition, and Representation, ed. Bakker and Thijssen (Aldershot: Ashgate, 2007), 87-107. 
So far so good. However, Durand goes on to extend the argument to acts themselves. Suppose this one power by which I judge that whiteness is different from sweetness is the intellect, for the sake of argument. (It could be the common sense too.) Now, suppose that the intellect grasps whiteness by means of one mental act, M1, and sweetness by means of another mental act, M2. According to Durand, this will not suffice. He writes:

When there are [two] apprehensions [i.e. mental acts] that are such that not only each on its own but both together are about absolute objects, then the [relation of] sameness or difference between these [two absolute] objects, since it is a relation, can be grasped neither through one of these apprehensions nor through several [i.e., both] together. ${ }^{13}$

In the case at hand, M1 has something absolute as its content (whiteness) and M2 likewise has something absolute as its content (sweetness). However, the content of my judgment that whiteness is different from sweetness includes not just these two absolute things but also something non-absolute, namely, the relation of difference between them. Hence, mental acts M1 and M2 are insufficient.

Why can we not suppose that, in addition to M1 and M2, there exists at the same time a third mental act, M3, through which the intellect grasps the relation of difference between whiteness and sweetness? Durand's answer is as follows. Either M3 has as its precise content something relational (i.e., the relation of difference), in which case we would be committed to the peculiar position that a mental act has as its content just a relation without the relata of that relation, or M3 has as its content whiteness, sweetness, and the relation of difference between them - but, then, why not apply some moderate principle of economy to the whole affair and suppose that M3 on its own is sufficient? ${ }^{14}$

${ }^{13}$ Ibid., 490.20-23: "[...] ubi apprehensiones (apprehensionum ed.), non solum quaelibet secundum se sed ambae simul, sunt de obiectis secundum se et absolute, ibi, nec per unam talium apprehensionum nec per plures simul, potest poni convenientia vel differentia obiectorum, quia talis est respectus (respectio ed.) [...]" See also ibid., 490.13-18. Compare with Wylton, Quaestio "Quod in intellectu..."; Prosper, Sent. 1.1.3.1, f. 79ra; Baconthorpe, Sent. 2.10.1, f. 530a: "[...] ubi utraque apprehensio est proprii (principium[!] Wylton) obiecti secundum se et absolute, ibi ambae intellectiones erunt de diversis obiectis secundum se et absolute."

${ }^{14}$ Ibid., 491.21-30: "If it is said that, in addition to these two acts, a third act is necessary, which is [the act of] composition or division, against: Either with this [third] act (a) [both] the [relation of] composition and the relata of the [relation of] composition are thought about, or (b) just the [relation of] composition without the relata. If (a), then this [third act] is superfluous. If (b), then the [relation of] composition is thought about 
Since what goes for the relation of difference goes for any relation, ${ }^{15}$ the upshot is that for Durand such judgments - thoughts about distinct objects as related - require a kind of unity: not just of subject, and not just of power, but of act. In order to judge that A is related to B, we must grasp A, $B$, and the relation, $R$, between $A$ and $B$ with a single unified act.

Admittedly, Durand's unity-of-act argument appeals to a kind of principle of parsimony; but as with any invocation of the razor, an opponent might respond by insisting that more must be added. Thomas Wylton does just that. According to Wylton, responding directly to Durand, in order to judge that whiteness is different from sweetness, a mental act about whiteness, M1, and a simultaneous mental act about sweetness, M2, are both necessary in addition to a (simultaneous) mental act about whiteness, sweetness, and the relation of difference between them (i.e., M3), for otherwise I would not know if my judgment is true or false. ${ }^{16}$ He makes a similar move when analyzing our knowledge of the conclusion of a demonstrative syllogism. When I know a conclusion, I must know that I know that conclusion, and this entails, at least for Wylton, that I must

without [also thinking] this: that something is composed (ergo intelligitur compositio sine hoc quod aliquid componatur), which is impossible and contrary to the Philosopher[...]" See also ibid., 489.23-30, quoted in the next footnote. For a discussion of this passage in particular, see Friedman, "Mental Propositions," 99-100 and Pasnau, After Certainty, 291.

${ }^{15}$ Ibid., 489.39-41: "No power can hold that things are different from each other, or the same as each other, or apprehend any relationship (habitudo) whatsoever between some things, since the same account applies to them all, unless it apprehends each [thing] together [with the same act]." See also ibid., 489.23-30: "An ordering (ordo) or any relationship (habitudo) whatsoever between multiple things cannot be cognized without the relata of that ordering or relationship, for just as it is impossible to think about the [relation of] composition or division between some things without thinking about the composed or divided relata, so too it is impossible to think about the ordering or relationship between multiple things without also thinking at the same time about the relata of that relationship or ordering, no matter what sort of relationship this might be, e.g., one of sameness (convenientiae), difference (differentiae), opposition (oppositionis), separation (disparationis), etc. Hence, someone who cognizes something as ordered to or in a relationship with something else necessarily cognizes each of them at the same time through the same act."

${ }^{16}$ Quaestio "Quod in intellectu..." 508.18-20: "Someone who is dividing or composing some things with respect to each other cognizes them under their proper concepts just as they compose [or divide] them[...], for otherwise they would not know if they truly or falsely composed them (nesciret si vere componeret vel false)." 
simultaneously grasp that the premises in themselves are true and necessary. Hence, one act that is about both the premises and the conclusion (together with the relation of entailment) is insufficient for knowing that conclusion: I must elicit multiple simultaneous acts. ${ }^{17}$

While we do not have Durand's reply (if any) to Wylton's objection, Durand does have the resources to face it, I submit, if we look at another discussion of the unity-of-act argument, namely, Sent. 1.38.2. In that text, Durand maintains again that the judgment that whiteness is different from sweetness is just one act (i.e., M3). However, he adds an important clarification. M3 is one act that virtually (but not really) contains two other acts: M1 (about whiteness) and M2 (about sweetness). ${ }^{18}$ (Wylton, by contrast, maintains that M3 is a kind of 'composite' act that really contains acts M1 and M2.) ${ }^{19}$ Durand draws an analogy with softness, dryness, and

${ }^{17}$ Quaestio "Quod in intellectu..." 507.40-44: "If someone actually knows a conclusion, then [...] they will know that they know it, and so it is necessary that at that moment wherein they actually know the conclusion they not just cognize the premises as related to the conclusion [i.e. act M3], but also that the premises in themselves are true [i.e. acts M1 and M2], for otherwise, at that moment, they would not know that they know the conclusion." See also ibid., 506.4-7. For a discussion of both of these arguments, see Friedman, "Mental Propositions," 97-99.

${ }^{18}$ Sent. 1.38.2, n. 5: "[...] the intellect, thinking by composing and dividing, thinks about those things which it composes or divides with one essentially simple act (uno actu simplici per essentiam), which, however, virtually contains (virtute continet) the two antecedent acts with which we thought about human being on its own (seorsum) or animal or donkey on its own (seorsum) [... This] act virtually contains (continet virtualiter) the two antecedent acts [...] even though it is simple in its essence (simplex in sua essentia) [...] The intellect [...] thinks about distinct intelligible things with distinct acts [...] which are necessarily presupposed to a third act which virtually contains (virtualiter continet) them; and this third act would not exist if these [antecedent acts] had not existed beforehand." Sent. A 2.38.3 ad 4, n. 17 (also present in four manuscripts that witness to Sent. B): "The composite act [...] virtually contains the two antecedent simple acts, that is, what was understood about the predicate and what was understood about the subject (virtute continet duos actus simplices praecedentes, scilicet intellectum praedicati et intellectum subiecti)." For discussion, see Friedman, "On the Trail," 453, fn. 52 and "Mental Propositions", 101.

${ }^{19}$ Quaestio "Quod in intellectu..." 508.12-14: “[...] there cannot be such a composite act except insofar as it is composed out of multiple acts of thinking." Ibid., 511.17-26: "[...] it contains (comprehendit) two simple acts of thinking[...] This comparative act (comparativus actus) contains (comprehendit) in itself the two simple acts through which the intellect 
wetness to elucidate this notion of virtual containment. Softness is just as much a simple quality as dryness and wetness are; however, softness virtually contains both dryness and wetness insofar as it exhibits certain features of each: like a dry thing (but unlike a wet thing) a soft thing holds its own shape, but like a wet thing (and unlike a dry thing) it is easily molded. ${ }^{20}$ Applied to the case at hand, we might suppose that a mental act, $\mathrm{C}$, that virtually contains acts $\mathrm{A}$ and $\mathrm{B}$ includes in its content (at least) the content that A and B would have had on their own. Hence, M3 (the judgment that whiteness is different from sweetness) includes in its content whiteness and sweetness; M3 is about or represents what M1 and M2 would have been about or represented on their own. Thus, as a reply to Wylton's objections, Durand could simply insist that since M3 includes in its content at least what M1 and M2 on their own would have included in their content, we do not need to maintain that such judgments require M1 and M2 as simultaneously existing acts with M3. M3 should be sufficient for providing me with the requisite content to know, e.g., that the premises are true in themselves or that the composition is a true composition. ${ }^{21}$

cognizes each of the relata which it compares to each other under their proper concepts." Francis of Marchia, who also responds to Durand here, holds a similar view. See, e.g., Sent 1.1.7, 531-32, where he tells us that the two simple acts are 'materially' or 'dispositively' (materialiter et dispositive) contained in the third composite act. For discussion, see Friedman, "Mental Propositions," 106-112.

${ }^{20}$ Ibid., n. 5: "We say that wetness and dryness are simple qualities, whereas softness is a composite quality; however, softness is as simple in its essence as the others (in essentia sua est aeque simplex ut aliae). It is called 'composite' because it somehow virtually contains (aliquo modo continet virtualiter) wetness and dryness, for insofar as something soft is easily molded (facile cedit), it retains (retinet) the nature of wetness; and insofar as it holds its own shape (est terminatum termino proprio) it retains the nature of dryness. Likewise, in the case at hand, the third act virtually contains (continet virtualiter) the two antecedent acts, and so it is called 'composite' even though it is simple in its essence (simplex in essentia sua)."

${ }^{21}$ Durand's theory of virtual containment found its proponents, e.g., Palude, Quodl. q. 6, f. 102va and Sent. 1.38.2 (Barcelona, Archivo Capitular de la Santa Iglesia Catedral 35), f. 173va; Baconthorpe, Sent. 1.1.2, ff. 64b-65a; 2.6.1, ff. 512a-15b; and 2.10.1, ff. 534a-35a; and, more famously, Rimini, Lectura, Prologus, q. 1, whose version of the view came to exhibit some considerable influence on the 16th-century debate about the structure of propositions; see E. Jennifer Ashworth, "Mental Language and the Unity of Propositions," Franciscan Studies 41.1 (1981): 73-96, doi:10.1353/frc.1981.0004. On the connection between Durand and Rimini (who, incidentally, rejects the one-act-at-a-time thesis - and precisely 
With this in mind, then, let us now turn to Durand's contention that reflex acts and direct acts are not really distinct.

\section{Reflex Acts.}

In the fifth opening argument to QLA q. 3, Durand considers the following argument against the one-act-at-a-time thesis. Suppose I am thinking about a rose (a direct act) and at the same time thinking that I am thinking about that rose (a reflex act). Call this a case of mental reflection properly socalled. As the argument puts it, in such a case

the direct act and the reflex act are two acts; but these exist at the same time[...]; therefore, two acts can exist in the same power at the same time. (486.25-27)

Note that both Durand and his opponent here accept the minor premise in the above argument, namely, that in a case of mental reflection properly socalled the direct act and the reflex act exist at the same time. Call this the simultaneity thesis. This might seem trivially true - after all, if the direct act did not exist at the same time as the reflex act, then I would not be thinking that I am now thinking about a rose, but instead that I was thinking about a rose. However, some philosophers rejected the simultaneity thesis. John Baconthorpe, for instance, motivated in part by his commitment to the one-act-at-a-time thesis, insists that mental reflection properly so-called does not involve two simultaneously existing mental acts. According to Baconthorpe, just as when I think about a rose all that is needed is a representation of the rose and not an actually existing rose, so too in the case at hand: when I (reflexivly) think about a direct act of thinking, all that is needed is a representation of a direct act of thinking and not an actually existing direct act of thinking. Hence, in such a case, there is just one actually existing act (the reflex act) which is about another act (the direct act) that does not actually exist at that time. ${ }^{22}$ Since both Durand and his

Durand's arguments for it - even though he still adopts a unity theory of propositions much like Durand), see Friedman, "Mental Propositions," 113115.

${ }^{22}$ As Baconthorpe puts it, it is objectively (obiective) present but not really present (realiter). See Baconthorpe, Sent. (ed. Jeschke, Deus ut tentus vel visus) 1.1.1, 595-613 and Radulphus Brito, Quaestio "Utrum actus rectus et reflexus sint unus actus" (Vatican, lat. 1086), ff. 205va-206rb, who might be the source for Baconthorpe's view, and whose view is attacked by John of Pouilly, Palude, and Durand. (Or at any rate, since we cannot date Brito's text very exactly, the view Brito endorses is verbatim at times the view we find under attack.) See Pouilly, Quodl. (ed. Jeschke) 5.7, nn. 37-41, 698-99; Palude, Quodl. q. 6, f. 103va-vb; and Durand, QLA q. 3, 497.21-24. Prosper (Sent. 1.1.3.1) quotes from Brito's quaestio on f. 80ra-b in Vatican, lat. 1086 
opponent accept the simultaneity thesis, I will leave this option to one side. $^{23}$

Now, clearly if one endorses the view that the intellect can elicit or have only one act at a time, as Durand does, and one also endorses the simultaneity thesis, as Durand does, then one must reject the major premise in the above argument - that the direct act and the reflex act are distinct acts - and with it the higher-order theory of state consciousness, as Durand does. ${ }^{24}$ If, however, one maintains the simultaneity thesis but rejects

and attributes the quotation to M. Radulphus Brito in the margin. On some interpretations of Aquinas, this is his view too; see, e.g., Robert Pasnau, Thomas Aquinas on Human Nature (Cambridge: CUP, 2002), 345-347; for alternative interpretations of Aquinas, see the footnote after the next.

${ }^{23}$ Durand's argument for it is quick (497.24-27): "It is impossible that whiteness exist in a subject and yet that subject not be formally a white thing in virtue of whiteness; so too it is impossible that some act of cognizing exist in the intellect and yet the intellect not be formally a cognizing thing in virtue of it; thus, it exists as a cognition and not just as a cognized item." For a similar argument, see Palude, Quodl. q. 6, f. 103ra, 103va-b and Pouilly, Quodl. 5.7, n. 40, 699. Another common argument runs that the proposition, "I am now thinking about a rose," would be false were simultaneity not true. See here Pouilly, ibid., nn. 36-40, 698-99; Guy Terrena, Quodl. 1.14, n. 9, 460; and Palude, ibid., f. 103va, among many others (but not Durand).

${ }^{24}$ Examples of same-order theorists who are motivated by both the one-actat-a-time thesis and the simultaneity thesis include John Pouilly, Quodl. 5.7 (for discussion, see Jeschke, Deus ut tentus vel visus, 227-48) and Palude, Quodl. qq. 6, 9, 11; Sent. (ed. Jeschke) 1.1.1, a. 3, 743-47; and Sent. (ed. Jeschke) 4.49.4, a. 3, 780-89. In Quodl. q. 6, f. 102vb, Palude, not unexpectedly, interprets Aquinas as holding a same-order theory. While Aquinas definitely defends the one-act-at-a-time thesis (see footnote 3 above), he seems to offer us two different views about reflex acts. On the one hand, he seems to maintain a kind of same-order theory, e.g., Sent. 1.1.2, a. 1 ad 2: "[...] eadem operatione intelligo intelligibile et intelligo me intelligere." On the other hand, he seems to maintain, perplexingly, something like a higher-order theory, e.g., Summa theologiae 1.87.3 ad 2: "[...] alius est actus quo intellectus intelligit lapidem, et alius est actus quo intelligit se intelligere lapidem[...]" According to Palude, in the latter text Aquinas is not talking about mental reflection properly so-called, but about remembering. On Aquinas on this issue, see Cory, Aquinas on Human SelfKnowledge, 134-73, and the texts cited therein, who interprets Aquinas as holding the same-order theory. For the differing interpretations of Aquinas, see especially ibid., 136, fns. 4-7. See also, more recently, Rode, Zugänge zum Selbst, 37-60 and Brower-Toland, "Self-Knowledge," Forthcoming. 
the one-act-at-a-time thesis, then one could either defend the higher-order theory, as the opponent here does, ${ }^{25}$ or one could reject the higher-order theory, but for reasons orthogonal to the debate about whether or not a given mental power can elicit multiple mental acts at the same time. (This appears to be the case with Walter Chatton, who rejects both the one-act-ata-time thesis as well as the higher-order theory of state consciousness. According to Chatton, what makes an act conscious is not a reflex act about it but the fact that it was received in a suitable power. $)^{26}$

In his reply, then, to the fifth objection, Durand first divides the phenomenon of mental reflection into two basic sorts: remembering a past act of thinking about the rose, on the one hand, and thinking about a present act of thinking about the rose - mental reflection properly so-called - on the other. As we will see, Durand is not merely being pedantic here.

${ }^{25}$ Examples of higher-order theorists who reject the one-act-at-a-time thesis and embrace the simultaneity thesis include Guy Terrena, Quodl. 1.14; Prosper, Sent. 1.1.3.1; Ockham, Reportatio (ed. Gál and Wood 1981) 2.17; Quodl. (ed. Wey 1980) 1.12 and 1.14; Wodeham, Lectura secunda (ed. Wood and Gál 1990), Prologus, q. 2, 1:53-64; and William Crathorn, Sent. (ed. Hoffman 1988) 1.2, 180. On Guy, see Friedman, "On the Trail," 451. Note that Guy's rejection of the one-act-at-a-time thesis is limited to just reflex and direct acts: in general the intellect can have or elicit only one act at a time, but owing to the special 'connection' between a reflex and direct act, mental reflection proves the exception to the rule (ibid., nn. 9-11, 460-61). On Ockham, see Rode, Zugänge zum Selbst, 223-48; Lydia Deni Gamboa, "Can We Reflexively Access the Contents of Our Own Perceptions?," British Journal for the History of Philosophy 27.5 (2019): 921-40, doi:10.1080/09608788.2018.1537255; Susan Brower-Toland, "Medieval Approaches to Consciousness: Ockham and Chatton," Philosophers' Imprint 12.17 (2012): 1-29; "William Ockham on the Scope and Limits of Consciousness," Vivarium 52.3 (2014): 197-219, doi:10.1163/1568534912341275; and Sonja Schierbaum, "Ockham on the Possibility of SelfKnowledge," Vivarium 52.3 (2014): 220-40, doi:10.1163/1568534912341276. On Wodeham, see Rode, 261-79.

${ }^{26}$ Chatton, Sent. (ed. Wey 1989), Prologus, q. 2, a. 5. Chatton distinguishes such a (pre-reflexive) experience of the received act from a reflex act, which he argues is a distinct simultaneous act (ibid., 126-27). For discussion, see Rode, Zugänge zum Selbst, 249-60; Charles Girard, "Some Medievals and Brentano on Reflexivity and the Structure of Mental Acts," Topoi, Forthcoming; Brower-Toland, "William Ockham on the Scope and Limits of Consciousness"; and "Medieval Approaches to Consciousness." I'll discuss some of the differences between Chatton and Durand below. Another thinker who also rejects the one-act-at-a-time thesis but still considers a same-order theory like Durand's viable is Francis of Meyronnes (Sent. [Venice 1520] 1.3.11, f. 28rb-vb); see below footnote 34 . 
His analysis of remembering will help to illuminate mental reflection properly so-called, for both have the same basic structure, namely, both are cases of thinking about two distinct objects as related (i.e., Case B).

According to Durand, when I remember that yesterday I was thinking about a rose, I am thinking about a rose (thanks to a representation of the rose) and also the past act with it (i.e., the act that I elicited yesterday about the rose), and I do so with just one act. Durand writes:

From the presence of the rose, however it might be represented to me, I jump (consurgo) not just to a cognition of the rose but also to a cognition of the [past] cognition had before about the rose. Hence, the one [i.e., the rose] is a cognitive means with respect to the other [i.e., the cognition had before about the rose] (unum est ratio cognoscendi alterum), and so they both fall under one act, as was proved earlier. (Ibid., 497.3-6)

Recall the cognitive means argument discussed above. When I judge that smoke is caused by fire, smoke is used as a cognitive means with respect to fire: I cognize fire thanks to my cognition of smoke and the causal relationship in which it stands to fire. As a result, I cognize both smoke and fire at the same time and with the same act. Indeed, as the unity-of-act argument establishes, I must cognize both with one and the same act. So too in the case at hand. When I remember that yesterday I was thinking about a rose - or better: when I judge that the rose was thought about by the past act - the rose functions as a cognitive means with respect to the past act: I cognize the past act thanks to my cognition of the rose and the relationship (of having-been-thought-about) in which it stands to the past act. Hence, I can (and must) grasp both (rose and past act) with a single act at the same time.

Durand goes on to apply the same sort of analysis to mental reflection properly so-called. When I think that I am now thinking about the rose, I judge that the rose is now being thought about by a present act. The rose, once more, functions as a cognitive means, but this time with respect to a present act rather than a past act.

When I think that I am thinking about the rose, there is only one primary object (unicum principale obiectum), ${ }^{27}$ namely, the rose, and it is through a relation from this object that I cognize whatever

${ }^{27}$ Reading 'principale' for 'potentialem'. The contrast is with a secondary object (obiectum secundarium); see Sent. 1.35.1, nn. 14-16 and 1.36.3, nn. $10,13,26$. According to Durand, when I cognize A and B such that A is the cognitive means with respect to $B$, then $A$ is the primary object and $B$ the secondary object. Palude holds much the same view (Quodl. q. 6, ff. 101rb, 102ra, 102va, and 104rb). The distinction can be found in Aquinas too (see the texts cited above in footnote 10). 
else is cognized during an episode of mental reflection (intelligibili reflexione). (Ibid., 497.28-30)

The rose stands in certain relations to various things in the world: it stands in a relation to whatever it resembles, to whatever caused it, to whatever it effects, and, as we saw, it might even stand in a relation to a past act of thinking about it. Here, Durand's point is that it also stands in a relation to a present act of thinking about it. During a case of mental reflection properly so-called, the rose (the primary object) is a cognitive means with respect to the present act of thinking about it (the secondary object). But since I must grasp the cognitive means and that with respect to which it is a cognitive means with one act at the same time, it follows that when I think that I am now thinking about the rose (or better: when I judge that the rose is now being thought about by my act of thinking) I elicit just one act that has as its content both the rose and that very act itself.

As before, multiple mental acts are either insufficient or redundant. Suppose for the sake of argument the opponent's view: I elicit a direct act about the rose and a distinct reflex act about that direct act, at the same time. These two acts alone would be insufficient for the judgment that I am thinking about the rose. Just as there must be one act that grasps (1) sweetness and (2) whiteness together with (3) their relation of difference in order for there to be a judgment that sweetness is different from whiteness, so too there must be one act that grasps (1) the rose and (2) the (direct) act, together with (3) the relation of being-thought-about in order to judge that I am now thinking about the rose (or alternatively: that the rose is now being thought about by my act of thinking). Nor can we insist that in addition to this one act there must be two other acts simultaneously present, one of which is about the rose, M1, and the other about the direct act, M2. As before, these two acts would be redundant, since the act with which I grasp all three - rose, direct act, and the relation of being-thought-about virtually contains both M1 and M2, that is, it includes in its content at least the content that these two mental acts (M1 and M2) would have had on their own. Multiple mental acts just will not do. The reflex act and the direct act are not really distinct; they are one and the same act.

Before I turn to an objection to Durand's account, I want to offer two brief remarks about Durand's same-order theory of state consciousness. First, like his higher-order opponent, Durand holds that the reflex act is about the direct act: the direct act is represented by (included in the content of) the reflex act. Hence, Durand holds that state consciousness is representational (or intentional) in character. Other same-order theories, e.g., Walter Chatton's, and on some interpretations, Aquinas's, maintain, by contrast, that our experience of our own acts is non-representational in character. Chatton, for instance, maintains that what makes an act conscious is the fact that it was received in a suitable power; but there is only an attenuated sense, at best, in which such reception is about the direct act. Indeed, 
Chatton strongly insists that we not treat such a (pre-reflexive) experience of our received acts as an experience of an object. ${ }^{28}$ In this way, Durand's view would align more readily with, say, Brentano's same-order theory and certain contemporary same-order theories, e.g., Uriah Kriegel's same order monitoring theory, which maintain that state consciousness is representational (or intentional) in character. ${ }^{29}$

Second, Durand holds that the direct act is a part of the reflex act. When I judge that whiteness is different from sweetness, there is a single mental act, M3, that virtually contains acts M1 (about whiteness) and M2 (about sweetness); so too when I judge that I am thinking about the rose: there is a single mental act, M3, that virtually contains acts M1 (about the rose) and M2 (about the direct act about the rose). As suggested above, we should understand the notion of virtual containment here in terms of content. If act $C$ virtually contains acts $A$ and $B$, what this means is that the content of $C$ includes (at least) whatever content A and B would have included on their own - it does not mean pace Wylton that $\mathrm{C}$ really contains acts $\mathrm{A}$ and $\mathrm{B}$. So too here. The single (reflex) act, M3, with which I judge that I am thinking about the rose, virtually contains acts $\mathrm{M} 1$ and $\mathrm{M} 2$, that is, it includes in its content at least what M1 and M2 would have included in their content on their own, namely, the rose and the (direct) act. Hence, although on Durand's view the reflex act and the direct act are one and the same act, there is a sense in which we can say that the direct act is a 'part' of the reflex act. It is, I submit, a logical part of the content of the reflex act just as much as the rose is a logical part of the content of the reflex act. ${ }^{30}$

${ }^{28}$ Chatton, Sent., Prologus, q. 2, a. 5, e.g., 126: "Alio modo sumitur intelligere et videre intellectionem lapidis [...] scilicet pro receptione illius intellectionis lapidis in mente, quia mentem recipere intellectionem lapidis est experiri illam intellectionem, non sicut potentia experitur obiectum, sed sicut potentia experitur actum suum recipiendo." On Chatton, see the references in footnote 27 above. For this interpretation of Aquinas, see Brower-Toland, "Self-Knowledge."

${ }^{29}$ Indeed, the connection with Brentano is striking. See, e.g., Psychology from an Empirical Stand point, trans. Rancurello, Terrell, and McAlister (London: Routledge, YEARREF), II.3, n. 7, 119: “[Every conscious mental act] has a double object, a primary and a secondary object. The simplest act, for example, the act of hearing, has as its primary object the sound, and for its secondary object, itself, the mental phenomenon in which the sound is heard." See also ibid., II.2, n. 7, 93-97. For discussion of the connection between Brentano and Durand, see Perler, "Are Reflexive Acts Possible?" and Girard, "Some Medievals and Brentano on Reflexivity." On Kriegel, see the next footnote.

${ }^{30}$ On same-order theories cashed out in terms of a logical part-whole relation, see Kriegel, "The Same-Order Monitoring Theory of 


\section{Peter \& Guy's Ubiquity Objection}

In close, I want to consider an objection that at least two of Durand's contemporaries raised against his account. If reflex acts are not distinct from direct acts, then, it would seem, I would be aware of all my mental acts, that is, then all my mental acts would be conscious. Call this the ubiquity objection. As Peter of Palude puts it (Quodl. q. 6, 130ra-b):

Some people also draw the conclusion that a direct and reflex act not only can coexist but also that they always and necessarily do coexist. (Quidam etiam concludunt quod actus rectus et reflexus non solum possunt esse simul sed etiam quod semper et necessario sunt simul.)

Palude, at least, argues that this is an untenable claim, for it would seem to entail that we are always aware of all our mental acts, which, as Palude quips, is not (f. 103rb) "in line with what we all experience alike" (ad illud quod conformiter experimur). ${ }^{31}$ Or, as Guy Terrena puts it, coming at the objection from a different angle:

If two things are really the same, then it is impossible that one exist while the other does not; but a direct act can exist while a reflex act does not. For instance, I can think that I am alive without thinking that I am thinking that I am alive. (Quodl. 1.14, n. 7, 459) $)^{32}$

Consciousness," 145-46: "Another version of SOMT [i.e., the same-order monitoring theory] appeals to the part-whole relation[...] The relevant notion of parthood here is not spatial or temporal, but logical[...] When I am glad that the weather is nice, I necessarily also believe that the weather is nice; it is impossible to be glad that the weather is nice without believing that this is so. But my belief that the weather is nice is not an extra mental act, which occurs in addition to my gladness. Rather, the belief is somehow inherent in, or built into, the gladness. In other words, my belief is part of my gladness, in a logical sense of 'part of'." Kriegel goes on to define no less than six different versions of SOMT that appeal to a logical part-whole relation. Noteworthy is the fifth (148): "A mental state M of a subject S is conscious iff $S$ has a mental state $M^{*}$, such that (i) $M^{*}$ is a representation of $\mathrm{M}$, and (ii) $\mathrm{M}$ is a (proper part) of $\mathrm{M}^{*}$." This, I submit, is precisely Durand's view.

${ }^{31}$ Perhaps conformiter should read communiter instead.

${ }^{32}$ Baconthorpe adduces this argument as well in Sent.1.1.1, a. 2, n. 34, 604 , where he uses it as further support for his refutation of the simultaneity thesis (see above footnote 23). Pouilly, Quodl. 5.7, nn. 47-56, 701-703, recognizes the objection. Ockham adopts it as his own in Reportatio 2.17, 5:386, and Wodeham uses it in his criticism of Chatton (Lectura secunda, Prologus, q. 2, 1:58-59). For discussion, see Brower- 
Sometimes I am just thinking about the wine in front of me and not thinking about my thinking about the wine in front of me; but if direct acts are really the same as reflex acts, then such a case would be impossible.

Before I turn to how Durand might answer such objections, it will be useful to draw a distinction between two forms of consciousness: introspective consciousness and phenomenal consciousness. A mental act or state is phenomenally conscious when there is something it is like to have that mental act or be in that mental state. A mental act or state is introspectively conscious when one takes a step back, as it were, and reflects upon it, i.e., when it somehow features as an object of a (reflex) act. For instance, when I taste the wine in front of me, such an act might be (and usually is) phenomenally conscious; but in order for it to be introspectively conscious I must take a reflexive step back, as it were, and think about it. ${ }^{33}$ Peter and Guy seem to be insisting, reasonably enough, that not all mental acts are introspectively conscious, a desideratum on a theory of state consciousness that Durand's theory, committed as it is to the identity of reflex and direct acts, seems incapable of satisfying.

Durand, I submit, denies ubiquity in the case of introspective consciousness. This is clear if we look at an especially thorny argument - call it the argument from memory - found in QLA q. 3 ad 5. I'll quote it in full and then unpack it.

When I cognize that I am cognizing a rose, there are not two acts, but rather there is only one act. (A) For no (at least no perfect) intellective act lies hidden from the intellect, because a cognition that exists in a cognizer cannot lie hidden from the cognizer. However, we do not always fully discern this [sc. that we are cognizing]. This is clear because (1) an act of remembering can only be about something cognized beforehand; (2) but there can be an act of remembering about every act through which we (at least perfectly) cognize something. However, at that very moment we might not discern that we are cognizing. (A*) Therefore, every such act was not just a cognition but also cognized. (B) Nor was it cognized through an act other than itself. (497.6-13) ${ }^{34}$

Toland, "Medieval Approaches to Consciousness," 23-25. On the contemporary form of the ubiquity objection, see, e.g., David Armstrong and Norman Malcolm, Consciousness and Causality (Blackwell: Oxford, 1984), 121-22.

${ }^{33}$ Sometimes the distinction is captured in the contrast between monitoring consciousness and phenomenal consciousness. See Ned Block, "On a Confusion about a Function of Consciousness," Behaviorial and Brain Sciences 18 (1995): 227-287. 
Now, (1) and (2) merely establish the claim (A/A*) that every perfect act (at least) must itself be cognized. It does not establish (B) - that every perfect act (at least) must be cognized through itself and not through some other (higher-order) act. Presumably, Durand must hold that (B) is established from arguments he has already made, e.g., the cognitive means and the unity-of-act arguments; otherwise I can make little sense of how (B) follows from $\left(\mathrm{A} / \mathrm{A}^{*}\right){ }^{35}$

Regardless of the success of the argument itself, what Durand says in the text set in italics clearly shows that he denies ubiquity in the case of

${ }^{34}$ Ibid.: "Quando autem cognosco me cognoscere rosam, nec tunc sunt duo actus sed unus. (A) Nullus enim actus intelligendi, saltem perfectus, latet intellectum, quia cognitio inexistens in cognoscente non potest ipsum latere, quamvis hoc non discernamus semper ad plenum. Et hoc patet, quia (1) recordatio non potest esse nisi alicuius praecogniti; (2) sed omni actu quo aliquid cognoscimus, saltem perfecte, etiamsi pro tunc non discernamus nos cognoscere, potest esse recordatio; $\left(\mathrm{A}^{*}\right)$ ergo omnis talis actus fuit non solum cognitio sed etiam cognitus; (B) nec cognitus alio actu quam seipso." See also Palude's presentation of the argument (Quodl. q. 6, f. 103ra-b): "Dicunt enim quod nihil potest esse in memoria quod prius non fuit in intelligentia; sed quicumque semel intellexit aliquid potest recordari se illud intellexisse; ergo prius intellexit se illud intelligere; sed non potest intelligere se intelligere nisi dum intelligit[...]; ergo quicumque intelligit aliquid <intelligit etiam > se intelligere illud; et sic non potest esse actus rectus sine reflecto (reflectio $M S$ ); sed sicut non semper percipitur actus rectus secundum se, sic nec actus reflexus, secundum eos." See also ibid., f. 103ra. Francis of Meyronnes (1320s) makes the same argument, presenting it as one of his own in defense of the same-order theory, although he winds up not deciding between the same-order and the higher-order theory (Sent. 1.3.11, f. 28va): "Alias rationes adduco fortiores, supponendo quod nos possumus recordari de omni actu nostro quem ante habuimus. Hoc supposito suppono etiam aliud tamquam verum: Quod de nullo possumus recordari quod ante non intelleximus. Istis praesuppositis formatur sic ratio: Nullius possumus recordari quod non praefuit in intellectu; sed nos possumus recordari de omni actu quem ante habuimus; ergo omnis <actus> quem ante habuimus praefuit intellectus. Tunc arguo sic: Aut ergo omnes <actus> seipsis fuerunt intellecti aut aliis et aliis actibus. Si seipsis, tunc idem actus erit intelligens et intellectus, et per consequens idem erit rectus et reflexus. Si aliis et aliis, tunc vel dabis mihi ultimum, et tunc ille non erit intellectus, vel non dabis mihi ultimum, et tunc multiplicatur in infinitum, quod apparet satis inconveniens." A similar argument is discussed by Chatton in Sent., Prologus, q. 2, a. 5, 122 and 124-25.

${ }^{35}$ Meyronnes, in his version of the argument, establishes that (B) follows from $\left(\mathrm{A} / \mathrm{A}^{*}\right)$ on the grounds that otherwise an infinite regress would obtain (see the previous footnote). It is plausible that Durand had something 
introspective consciousness. Durand's claim in (A/A*) is that some (if not all) mental acts are cognized whenever we elicit them, since some (if not all) mental acts can be remembered. (For the sake of exposition, I will assume the stronger claim: all mental acts are cognized whenever we elicit them since all mental acts can be remembered.) ${ }^{36}$ However, Durand does not think that all mental acts are, thus, introspectively conscious, that is, that I am (introspectively) aware of (or discern) all my mental acts whenever I elicit them. Durand's claim in the italicized text is that even if a mental act is cognized, it does not follow that it is discerned, that is, it does not follow that I am (introspectively) aware of it. Consider: I might be so focused on the wine in front of me that I am oblivious of my thought about it, and yet, if you were to ask me what I was just doing then, I would answer that I was thinking about the wine. I was, one might say, implicitly (or I might even suggest phenomenally) aware of my mental act but not explicitly or introspectively aware of it; or, as Durand would put it, I cognized my mental act (since I could remember it) but I did not discern it. ${ }^{37}$ Hence, even though all mental

similar in mind, for both Baconthorpe (Sent. 1.1.1, n. 31, 603-604) and Palude (Quodl. q. 6, 103rb), reporting Durand's position, append an infinite regress argument to it. As Palude puts it: "Et confirmatur, quia activis et passivis debito modo approximatis necesse est fieri actionem et in instanti quando utraque potentia activa et passiva est in ultima dispositione. Unde quando intellectus intelligit, cum sit dispositus ultimate ad intelligendum se intelligere et <cum > activum - sive sit primum obiectum solum sive cum hoc sit ipse actus rectus et intellectus agens - sit (sint $M S$ ) etiam in ultimata dispositione nullam ulterius expectans (expectantes $M S$ ), statim fit ipse actus reflexus vel numquam. Et videtur mihi ratio efficax ad probandum indifferentiam realem actus recti et reflexi, quia impossibile est esse infinita actu simul distincta genere, specie, vel numero; sequeretur autem hoc posita differentia reali inter actum et reflexum; ergo etc."

${ }^{36}$ Meyronnes and Palude both make the stronger claim (see the previous two footnotes); this also seems to be the interpretation of the argument that Friedman puts forward in "On the Trail," 446-47. Durand does not tell us what he means by 'perfect act' here. Perler ("Are Reflex Acts Possible?" 221-23) interprets Durand to have in mind only those acts that are "so vivid that [they] cannot be ignored." Sven Knebel ("Durand, Quirós, Consciousness," in Durand of Saint-Pourçain and His Sentences Commentary, 359-60) maintains that 'perfect' acts are acts of "comprehensive knowledge". I would submit that a perfect act is simply an act which reaches the threshold for phenomenal consciousness.

${ }^{37}$ On explicit/implicit awareness, see especially Cory, Aquinas on SelfKnowledge, 134-37. It is not clear to me if Durand would characterize a mental act that is cognized but not discerned as phenomenally conscious in our sense of the term, that is, that there is something it is like to have that 
acts are cognized whenever we elicit them, not all mental acts are, thus, introspectively conscious.

But it is one thing for Durand to think that introspective consciousness is not ubiquitous and it is quite another to show how on his view it is not in fact ubiquitous. If the direct act and the reflex act are identical (one and the same act), then how can Durand allow for a direct act to exist on its own without a reflex (discerning) act? Durand's solution rests on his theory of virtual containment. As we saw above, according to Durand, during an episode of mental reflection properly so-called, i.e., when I think (discern) that I am thinking about the rose, there are not two distinct acts but just one act, such that the direct act is a part of the reflex act, i.e., it is virtually contained in the reflex act. However, notice that, on this view, while a direct act is a part of the reflex act, the converse is not true. Hence, it is no great mystery that a direct act might occur on its own without a reflex (discerning) act. Durand does not hold that the direct act and the reflex act are the same in a strict sense of identity, but rather that the direct act and reflex are one whole act. ${ }^{38}$

But what explains the fact that we discern a mental act in one situation whereas in another situation we do not? Durand doesn't say. ${ }^{39}$ Peter of Palude, who follows Durand on this quite closely, suggests that it is a function of the will. It is up to me to think about my thought about the rose if I want. ${ }^{40}$ Like Durand, Palude maintains that from the representation of an

act. However, what is important is that a mental act's being cognized is not the same as a mental act's being introspectively conscious. I would like to thank Susan Brower-Toland for discussion about this point.

${ }^{38}$ Hence, Durand's view should not only be sharply contrasted with sameorder theories that maintain a strict identity between direct and reflex acts, but also those which maintain that the reflex act is somehow a part of the direct act. On such views, see Kriegel, "The Same-Order Monitoring Theory of Consciousness."

${ }^{39}$ Unfortunately, Durand only talks about discernment in one other place of which I am aware, namely, Sent. C 1.27.2, n. 21; however, in his discussion of fruition (Sent. 1.1.1) he characterizes the same phenomenon using the verb perpendere (n. 21: neque enim omni modo est perfecta cognitio qua quis cognoscit rem aliquam per actum rectum nisi perpendat se cognoscere eam, quod fit per actum reflexum.) See also n. 22.

${ }^{40}$ Quodl. q. 6, f. 103rb-va: “[...] quia intelligimus cum volumus, intellectus inquirens cognoscere rem exteriorem tantum <et> non actum suum non est dispositus ad recipiendum actum reflexum, si differt, vel rectum ut reflexus est, si non differt; unde tunc non recipit ipsum. Sed postea, volens [autem] scire actum suum et animam, quasi excitatus ad actionem circa hoc per ipsam attentionem, disponitur ad actum reflexum recipiendum. Sicut: homo 
external object, e.g., the rose, I can think, with one and the same thought, about whatever it is to which that object is related, e.g., about fire from the representation of smoke through smoke's relation (of causality) to fire as a cognitive means, or, in the case at hand, about the (direct) act itself from the representation of the rose through the rose's relation (of being-thoughtabout) to that act. ${ }^{41}$ It is up to me to think about just the rose on its own, or, if I want, to go on and think about whatever it is that the rose might be related to. Nor does this entail that there will be two simultaneous intellective acts, one of which causes (excites) me to want to discern my thought and the other of which is the reflex (discerning) act itself by which I discern my thought, for, at least according to Palude, the former can execute its role as exciting cause without having to be present at the same time as the latter. ${ }^{42}$

\section{Conclusion}

Let us sum up. According to Durand, a given mental power (the intellect, say) cannot elicit or have two mental acts at the same time. It follows, then, that mental reflection properly so-called - when I think that I am thinking about the wine in front of me - cannot be a matter of my intellect's possession of two mental acts, one of which (the reflex act) is a higher-order

quandoque intelligit in universali asinum et nullum asinum in particulari, quod est possibile cum omne universale possit absolvi ab omni particulari. Postea vero simul cum asino in universali intelligit hunc asinum in particulari <intelligit eum > sine hoc quod accipiat novum phantasma sed $<$ intelligit eum> per idem (novum $M S$ ) phantasma huiusmodi asini quod prius habebat, quod prius repraesentabat universale et movebat $<$ intellectum $>$ ad cognoscendum ille < universale $>$ tantum, nunc vero movet ad <cognoscendum > utrumque [nunc vero movet ad utrumque] non propter variationem sui <sc. phantasmatis $>$ sed intellectus vel voluntatis quaerentis cognoscere nunc utrumque prius autem alterum tantum." See also ibid., ff. 104ra, 118rb.

${ }^{41}$ Quodl. q. 6, f. 118ra: "[...] si ex uno phantasmate possint plura cognosci, puta ex phantasmate fumi <possint cognosci> natura eius et ignis, et non curet homo nec cogitet de igne nec confuse nec aliter, occurrit sibi phantasma fumi ut repraesentans fumum; postea vero si sollicitetur aliquo excitante (excitate $M S$ ) interius vel exterius inquirere ulterius, cessabit actus primus et succedet secundus, <sed $>$ per idem phantasma quoad speciem phantasticam <ut> repraesentantem (repraesentans $M S$ ) fumum et ignem."

${ }^{42}$ Quodl. q. 6, f. 118ra: "Et licet ad intelligendum se intelligere de novo forte requiratur aliqua intellectio excitativa attentionis, ipsa tamen non est causa directa actus reflexi." 
act of or about the other (the direct act). Rather, what happens is this. I elicit one mental act which has as its primary object the wine in front of me through which, as a cognitive means, I also cognize that very mental act itself as secondary object at the same time. The unity-of-act argument demands this: in order to judge that the wine in front of me is now being thought about by a mental act, I must elicit one mental act that has as its content the wine in front of me, the relation it stands in to a mental act, and that very mental act itself. Nor does such a view fall into the trap of making introspective state consciousness ubiquitous, for I can attend to just the wine in front of me, or I can attend to the wine in front of me together with whatever else it might be related to, including, of course, my mental act about it. ${ }^{43}$

${ }^{43}$ I would like to thank Thomas Jeschke and Guy Guldentops for providing me with drafts of their editions of certain questions from Durand's Sentences. As well, I would like to thank the audiences at the St.-Louis Medieval Symposium 2019 and the Loyola Chicago - St.-Louis University Medieval Research Group 2019. Particular thanks are owed to Susan Brower-Toland, Charles Girard, Zita Toth, Deni Gamboa, Adam Wood, Martin Klein, Russell Friedman, and an anonymous referee for extremely helpful feedback on drafts of this paper. 